\title{
Efforts on Forest and Land Rehabilitation through the Promotion of Prospective Local Plants in Bengkulu Province
}

\author{
Dwi Arianto Harto Darsono ${ }^{1, *}$ \\ ${ }^{I}$ Gedung Manggala Wanabakti Blok IV Lantai 3 R.306, Jl. Gatot Subroto - Senayan, Jakarta Pusat
${ }^{*}$ Corresponding author. Email: ittopd477bengkulu@gmail.com
}

\begin{abstract}
One of the causes of failure in the Forest and Land Rehabilitation (FLR) activities in Bengkulu Province is due to lack of use of prospective local plants. In addition, it is also due to the low participation, capacity and awareness of the community as well as related parties (especially regional stakeholders) in the FLR activity itself. The ITTO's project entitled "Improving Forest Functions in Bengkulu Province through Community Participation in Rehabilitation of Degraded Forests by Using Local Prospective Commodities" has been implemented with the purposes to implement appropriate technology for the production of quality plant material from prospective local species and to improve the welfare of the community through the success of forest and land rehabilitation activities. The project has been implemented by the Ministry of Environment and Forestry in collaboration with Forestry Service of Bengkulu Province and the local communities. The promoted prospective local plants were Kayu Bawang (Azadirachta excelsa) and Bentara Durian (Durio zibethinus). The expected outputs of the Project were as follows: (1) Identification of seed sources and application of seedling propagation technology for the selected prospective local plants, (2) Preparation and dissemination of technical guidelines for prospective local plants seedling and planting technology, (3) Production and distribution of qualified prospective local plants seedling for the community, and (4) development of qualified local plants models (Kayu Bawang and Bentara Durian).
\end{abstract}

Keywords: Forest and Land Rehabilitation (FLR), Local Prospective Plants, Kayu Bawang, Bentara Durian.

\section{INTRODUCTION}

Forest utilization that disregards the principles of sustainability has become main factor of forest destruction in Bengkulu Province. The Head of Environment and Forestry Service of Bengkulu Province stated that as many as $657.049 \mathrm{Ha}$ area or $71 \%$ of total forest area in Bengkulu Province $(924.631 \mathrm{Ha})$ in degraded condition [1]. Harvesting method which is not considering to sustainability, illegal logging, encroachment and land conversion are several forms of unsustainable forest utilization.

On the other hand, Forest and Land Rehabilitation (FLR) program which is still being implemented has not shown a maximum result on overcoming of forest degradation. Furthermore, support on the sustainable forest management from local community and related parties (especially regional stakeholders) are also still not optimal yet. These obstacles such as forest utilization (which is not considering sustainability principles), unsatisfactory results of FLR program as well as low participation of local community and related parties in the forest management will lead into increasing poverty of the community around the forest. Their income from forest will decrease. In line with the limitation of alternative livelihoods of community from forest and weak law enforcement, will eventually accelerate the rate of forest degradation.

ITTO collaborates with the Ministry of Environment and Forestry (MoEF) (c.q. Directorate of Forest Tree Seed under the Directorate General (DG) of Watershed and Protection Forest Management) and Environment and Forestry Services of Bengkulu Province have formulated the issues on the FLR activity (usually involves local community and related parties, namely: (1) lack contribution of the prospective local plants on 
improving community welfare and (2) low participation, capacity and awareness of the community as well as related parties in the FLR activity itself. This is not different as stated by [2] that the success of rehabilitation project is generally characterized by active involvement of local communities as well as technical interventions that specifically to address the ecology causes of forest degradation which have caused various problems regarding the use of forest resources for local community.

In the further observation, the first issue in the above was due to three things that are deficiency seed/seedlings sources production, lack of mastery on the propagation technology as well as technology on seedling planting. While the causes of the second issue are also due to things, specifically: imprecise selection of the species and planting pattern, low understanding and less expertise on the propagation and planting of prospective local plants, as well as low awareness of local community in the FLR activity.

According to those issues that mentioned above, ITTO's project entitled ITTO PD 477/07 Rev. 4 (F) [3] "Improving Forest Functions in Bengkulu Province through Community Participation in Rehabilitation of Degraded Forest by Using Local Prospective Commodities" has been implemented. The objectives of the project are to implement appropriate technology for the production of quality plant material from prospective local plants and to improve community welfare through the success of the forest rehabilitation by using prospective local plants.

There are two site project locations for this activity, namely North Bengkulu District and Seluma District, Bengkulu Province. In North Bengkulu District, precisely it is located in Limas Jaya Village, Urai Village, Ketahun Sub-District. Whereas in Seluma District, the location is in the Giri Mulya Village, Ulu Talo Sub-District.

The project has been implemented since 2016 and expected to be executed at the end of 2018. Several expected outputs of the project were (1) Identification of seed sources and application of seedling propagation technology for the selected prospective local plants, (2) Preparation and dissemination of technical guidelines for prospective local plants seedling and planting technology, (3) Production and distribution of qualified prospective local plants seedling for the community, and (4) development of qualified local plants models (Kayu Bawang and Bentara Durian).

\section{RESULT}

\subsection{Identification of the Seed Source and Application of the Seedling Propagation Technology for the Selected Prospective Local Plants}

This activity was supposed to overcome problems on the species selection, the seed/seedlings source production and the obstacle of its propagation technology. The criteria of the prospective local plants must be in the form of timber forestry plants even native or exotic species that popular among community in Bengkulu and superior species in the form of sap wood products as well as could produce high economic value fruits. Various promotion local plants in this project are Kayu Bawang (Azadirachta excelsa (Jack) M. Jacobs), Bambang Lanang (Michelia valutida), Bengkulu Mango (Mangifera sp), Bentara Durian (Durio zibethinus) and Bengkulu Petai (Parkia sp). Based on discussion with local community and related parties, Kayu Bawang and Bentara Durian were selected as promotion of prospective local plants because these plants also compatible to the feature in the site location of FLR.

Qualified seed sources of Kayu Bawang and Bentara Durian were obtained through identification of the potential of seed source and mother plant exploration. Distribution area of Kayu Bawang covers almost the entire region of Bengkulu Province. As quoted by [4] that Kayu Bawang is one of the high quality tree species as common used species, Kayu Bawang has become preserved native wood commodities because of its high motivation from communities to plant it in its natural habitat. It is influenced by some factors inter alia the increasing demand for wood in the future and satisfying feeling towards timber business and trees maintenance.

In accordance to the result of identification and selection toward many potentials location of Kayu Bawang seed source by Regional Tree Seed Agency (RTSA/BPTH Wilayah I) I, then Penyangkak Village, Kerkap Sub-District, North Bengkulu District determinate as the location of Kayu Bawang seed source with grade "Identified Seed Stand" covering an area of 0.75 ha.

Whereas according to the Durian's mother plant exploration, it is chosen mother plant owned by Sutarkam where located in Batu Layang Village, Hulu Palik District, North Bengkulu. In 2005, actually, Durian's mother plant has been released by the Department (currently is called the Ministry) of Agriculture as superior species named Bentara Durian. [5] expressed that there are several predominance of Bentara Durian than the others which are: its fruit/seed has inverted oval shape, the fruit is easy to be split, Bentara Durian has fragrant aroma, very thick fruit flesh, small oval seeds (flat), yellow copper color fruit 
flesh, dried and fibrous fruit flesh texture, sweet fruit flesh taste (legit), its average weight range between 2.5$4 \mathrm{~kg} / \mathrm{pc}$, and adapt well in the lowlands area. The preferred thing about Bentara Durian is that its sugar content reaches 25.8 brix, meaning that the taste is the sweetest in its class. It has low fat content which is $4 \%$, $76 \%$ moisture, and fruit production rate can achieve $125-175$ pc fruit/year/season. Recently many same seed district-breeder have replicated this variety so that several alternatives of tree as mother plant are available (buds source of oculation).

In order to the FLR activity, seedlings propagation technology for Kayu Bawang and Bentara Durian had conducted in 2 (two) different methods. The propagation technique of Kayu Bawang using generative methods from seeds. The seeds obtained from predetermined seed source and/or individual tree that has considered-superior phenotype. Afterwards, the seeds bulked and planted. Kayu Bawang seed has recalcitrant character which means seeds must be planted soon as it harvested. Kayu Bawang seed can be stored only for up to 10 days and the rest, seed experiences decreasing germination ability drastically.

The supply of Bentara Durian seeds had carried out through purchased seedlings from the seed breeders of Bentara Durian. Its propagation was applied using vegetative material through oculation technique. There are 2 (two) type of Bentara Durian seeds provided namely white and blue labels. Both labels were issued by Seed Monitoring and Certification Agency (SMCA/BPSB) of Bengkulu Province. The white label implies that the rootstock and buds come from its original mother tree. Moreover, it means that the rootstock generated from seeding of durian seeds that was taken from the mother tree. Reciprocally, the buds which will grow to function as upper stem also were taken from the original mother tree. However, meaning of the blue label, rootstock came from seeding of random durian seeds and the upper stem came from buds taken out of mother tree cultivation.

In relation to the transfer knowledge of propagation technology, there were twenty persons representative from community and related parties such as extension staff and manager area (Forest Management Units/FMU) as beneficiaries. The technology transfers consist of theory and practice on Kayu Bawang and Bentara Durian propagation and planting techniques taught directly from the experts. The selected trainees were expected adequate to transfer and implement their knowledge to the community and other parties after training were held.

The beneficiaries have been trained how to produce Kayu Bawang seedlings initiated from managing seed source maintenance to the preparation distribution of seedlings in the nursery. In connection with Bentara Durian, the participants had studied on seedling oculation methodology and its maintenance until seedling ready to plant. In addition, the trainee got practice on seedling planting such as how to do proper planting procedures included ways to determine the type and amount of fertilizer requirements. The result of the training was expected that all of the beneficiaries (trainees) capable to manage supply and maintenance of qualified seedling plants, in this case are Kayu Bawang and Bentara Durian, as independently.

\subsection{Preparation and Dissemination of Technical Guideline for Prospective Local Plants Propagation and Planting Technology}

To improve community understanding and expertise on the seedlings propagation and planting techniques, the beneficiaries/ trainees were also provided with technical guideline on propagation and planting techniques for both of prospective local plants (Kayu Bawang and Bentara Durian). This guideline was arranged by involving experts from local universities who have competency in handling Kayu Bawang and Bentara Durian. Dissemination of technical guideline was carried out through project activity meetings and during field visits by the project implementers.

On top of that, community and related parties were directed to have an active role in the planning of plant models development for Kayu Bawang and Bentara Durian. The community and parties referred to mention above are residents of Giri Mulya village, Ulu Talo SubDistrict, Seluma District and staffs from Protection FMU of Seluma Districts and Production FMU of North Bengkulu District. Through workshops organized by the project, both villagers and FMU officers were actively involved in planning activity of plant models. Residents of Giri Mulya Village participated in the planning model of 3-hectare area on the village's land. Nevertheless, Protection FMU of Seluma District and Production FMU of North Bengkulu District have planned demonstration plots location respectively area covering of 2 ha and 5 ha. The model which managed by FMU, in its application was expected to continue optimize participation of the surrounding community.

For the record, after the implementation of Law 23 of 2014 concerning Regional Government, the management of forest areas is the authority of the Provincial Government. Districts no longer have authority. KPH becomes the Regional Technical Implementation Unit under the Provincial Government. 


\subsection{Production and Distribution of the Qualified Prospective Local Plants Seedling for the Community}

Upon completion of the training, the selected trainees attempted to be independent established Kayu Bawang seedling in their own homes. The yield of Kayu Bawang seedlings development expected to supply the needs on site. The production process initiated from seed treatment, seed and seedling maintenance to the seedling distribution lead to planting site location. However supply and distribution for Bentara Durian seedlings were carried out by breeder, because of its plant material limitation (especially the buds). The seedlings made are the blue label (spread seeds) and the white label (basic seeds). The white label seeds become the mother tree for seedling propagation activities. While the blue label are intended to fruits producer in plantations.

The most of remaining distribution seedlings for model were delivered to the community and related parties to be planted in their area. Community generally growth Kayu Bawang for hedge plant. Besides, FMU will use Kayu Bawang for main road divider/guard rail and also re-distributed to the community outside of the model location. As well as for the remaining Bentara Durian seedlings, community will plant it in their yard.

The selected trainees also have been tried to produce their own Bentara Durian seedling but still in the phase of seedling production for rootstock in the nursery. The seedlings derived from random durian seed. At oculation stage, they have planned to cooperate with the breeders. Meanwhile, the development of independent Kayu Bawang nursery by selected trainees which derived from regional stakeholder is convenient to be found. It is considering that planting for this species have become tradition. The availability of Kayu Bawang seed source in the North Bengkulu assists effectively for selected trainees to establish Kayu Bawang seedling nursery.

The project has initiated the establishment of Durian Bentara Hedge Orchard eventhough still using blue label to resolve limitation of buds material for Durian Bentara oculation supply. This hedge orchard located in Arga Makmur, the capital city of North Bengkulu District. Besides its limitation buds supply, hedge orchard development was also to anticipated the problem distance of the model location as mother tree provider. Furthermore, the development of this hedge orchard was expected to facilitate access in the provision of buds.

\subsection{Development of Prospective Local Plants Model (Kayu Bawang - Bentara Durian)}

Community, related parties and especially selected trainees not only involved in the planning model plants, but also participated in the development of Kayu Bawang - Bentara Durian models. The establishment was conducted upon review for the candidate location. The review consisted of analysis activities on vegetation and productivity of candidate locations before model establishment. This is useful to find out of location feasibility if it were planted with combination of Kayu Bawang and Bentara Durian.

The location of this development is in North Bengkulu District precisely in Limas Jaya Village and Urai Village, Ketahun Sub-district and these are inside of the Limited Production Forest (LPF) Air Ketahun (Register 70) area of around 14,447.27 hectares. The analysis result of satellite image in 2014, illustrated that condition of land use are mostly in the form of mixed dry agricultural land of around 12,865 ha area and the remaining use are for settlement, open land, shrubs and secondary dryland forest. Whereas in the model location, its vegetation cover was in the form of shrubs which has not managed for 6 years (local name: tanah bera).

In Seluma District, location of the model is in land of Giri Mulya Village of $3 \mathrm{Ha}$ and in LPF Air Talo of 2 $\mathrm{Ha}$ area. Giri Mulya Village has village land of $10 \mathrm{Ha}$, which is located towards to LPF Air Talo. The area is included in the category of non-productive land use in the form of shrubs which is not utilized by villagers. This land is located along the edge of main connecting road village. The land extends perpendicular toward village road, with flat to wavy topographic conditions. The altitude ranges from 200-250 meters above sea level. Several initial vegetation in this location was consisting of oil palm, fern, reeds, Jengkol (Archidendron sp), rubber plant, and any other uneconomical wild plants. Based on discussion forum with villagers, it was agreed that development of forest plants model will also conducted in this village's land.

LPF Air Talo has an area of about 2,282 Ha. Partial of this forest area have been cultivated by local community for agricultural activity illegally. The community exposed forest area sporadically and they cleared forest area by slashing to create a temporary field (shifting cultivation). Various types of agricultural crops such as upland paddy, eggplant, cucumber, tomatoes, patchouli and coffee planted on cleared land. After 2 years, it will abandoned by their owner for a new field. The fact is that the owner of the cleared land for shifting cultivation are not from Giri Mulya Village, but came from other areas that are quite far from the forest. 
Result of the study on the expectant of demonstration plot location showed that these three locations are included in secondary forest type with various composition of kind species and growth rate. In term of standing stock economy, no species of high economic value were found. In addition, stand diameter growth (increment) showed quite good result that is 3 $\mathrm{cm} /$ year. These are defined that index of land productivity is quite high and convincing enough to develop Kayu Bawang and Bentara Durian demonstration plots.

After land clearing, Kayu Bawang plant spacing was 2,5 m x $5 \mathrm{~m}$, while Bentara Durian spacing was $10 \mathrm{~m} \times$ $10 \mathrm{~m}$. Depari et al. (2013) as quoted by [6] stated that Kayu Bawang which grown with combination of coffee bars with an individual number around 3,000 trees/ ha, Kayu Bawang will have standing stock as amount 80 $\mathrm{m} 3 /$ ha at the age of 9 years.

Therefore, it is expected that combination planting of Kayu Bawang - Bentara Durian will produce standing stock cubication at least have same yields. The amount of Kayu Bawang planted in the model ranges from $243 \mathrm{pcs} / \mathrm{ha}$ up to $367 \mathrm{pcs} / \mathrm{ha}$ as shown detail in the Table 1.

In relation with model management, basically community and regional stakeholders having same opportunity by considering the ownership of existing model location. Commence from plants species selection to the model development, they had chances to involve directly by giving advices and obtain transferred knowledge and technology when interaction in the field. However, considering each person has different background of education, occupation and social status, it was impact to the difference ways on the model management and maintenance process. In the village's land, community strived directly on model maintenance. The opposite, community's role in the FMU location was more as laborer and received instruction from FMU officers.

\subsection{Problems Addressed and Project Performance}

Success indicator of FLR activity could be observed from many factors. There was no project can be assessed entirely successful or failed; after every aspect of the implementation are considered (viz. aspect of technical, socio-cultural, economy and institutional), the project usually success or fail only on certain aspect or stages depend on viewpoint of related stakeholders [2].

As mentioned before that objectives of this Activity project are (1) to implement appropriate technology for the production of quality plant material from prospective local species and (2) to improve the welfare of the community through the success of FLR activity with promoted local plants.

Considering the outputs generated from the project, the first objective has been achieved. The indicator of this specific objective achievement is produced and cultivated Kayu Bawang and Bentara Durian seedlings. Kayu Bawang seedlings derived through identification and selection techniques on qualified seed source. Meanwhile, Bentara Durian seedlings produced from the oculation method on the superior variety of mother tree. The project objective on the improvement of community welfare still cannot be assessed yet due to the short duration of project that is only 3 years.

In term of Forest and Land Rehabilitation, the activity implementation has represented attempts to restore and improve the forest and land functions. But, further research is still needed to evaluate whether forest and land have returned to their original functions or not. Moreover, this activity was solely carried out in the model scale.

From the above explanation indicates that outputs achievement have addressed several causes behind the execution of this project. The need of qualified prospective local plants seedlings has been fully achieved through the facilitation of seed and or seedlings source provisions and propagation technology

Table 1. The amount of seedlings planted in the 3 (three) model locations

\begin{tabular}{|c|c|c|c|c|c|c|}
\hline \multirow{3}{*}{ No. } & \multirow{3}{*}{ Location } & \multirow{3}{*}{$\begin{array}{l}\text { Area } \\
\text { (ha) }\end{array}$} & \multicolumn{4}{|c|}{ The amount of seedlings planted (Dec 2016) } \\
\hline & & & \multicolumn{2}{|c|}{ Kayu Bawang } & \multicolumn{2}{|c|}{ Durian } \\
\hline & & & Number (pcs) & $\%$ & Number (pcs) & $\%$ \\
\hline 1 & Giri Mulya Village's land, Seluma & 3 & 1,074 & 100 & 176 & 100 \\
\hline 2 & $\begin{array}{l}\text { LPF Air Talo - Seluma and Protection } \\
\text { FMU of Seluma }\end{array}$ & 2 & 486 & 100 & 154 & 100 \\
\hline 3 & $\begin{array}{l}\text { Limas Jaya Village, LPF Air Ketahun } \\
\text { and Production FMU of North } \\
\text { Bengkulu }\end{array}$ & 5 & 1,839 & 100 & 286 & 100 \\
\hline
\end{tabular}


as well as its planting. It is outright increase understanding of the community and related stakeholders on determination of species plant and its planting pattern.

However, the critical point of the project in the process achieving these outputs was the lack of capacity of community and related stakeholders. Not all of them have a good sensibility and response with the project activities. For example, only a few trained people had applied the result of the training on their hometown location. Even some of the participants, especially the community, were not involved actively for the maintenance activity in the demonstration plot.

Changes in the FMU structure that are now under the Provincial Government (after the implementation of Law Number 23) also affect. Some FMU officers who have been actively involved in project activities have slightly reduced their participation due to changes in the delegation's task policy by management.

Started from the model maintenance, the detail result of survived plants up to beginning of September 2018 is shown at the Table 2.

Based on the Table 2, described that the percentage of Kayu Bawang growth rate relatively better than Bentara Durian growth rate. It caused by major failure at the beginning of Bentara Durian planting. It was occurred especially in Seluma District with more than $90 \%$ of prospective plants die destroyed by wild boar. The circumstances of model location in North Bengkulu District relatively secure because of related parties (Production FMU of North Bengkulu) initiative to build individual fence for every durian seedling. Eventhough the mortality rate was quite high and considering the limitation of seedling supply, the replanting of Bentara Durian in the demonstration plot location of forest area in Seluma (about of $2 \mathrm{Ha}$ ) was not implemented optimally. Another obstacle is the rapid growth of reeds around the location. If not intensively maintained, within one month the surface of the location is covered by reeds.
The participation of community should have upgraded refers to the result of plant evaluation that the percentage of survived plant was promising in the model location of North Bengkulu. But, this is not portraying the presence of community participation in the maintenance. Involvement and initiative of the surrounding community in the maintenance process were still lacking. Most of the activities were managed by Production FMU of North Bengkulu with embraced the local labor of plantation around model location. Initially, low participation of community was happened in the village's land of Seluma. Then it was increased as the forestry extension of Protection FMU of Seluma was joined in this activity. The participation of community was began to exist along with the second year of plants maintenance. This cannot be separated from the direction and facilitation of the Extension Center (MoEF) and Environment and Forestry Service of Bengkulu Province in the form of strengthening farmer group institutions

In general, a regional stakeholder that is FMU had greater role on the development and maintenance of model located in forest area. This is because of tenure problem and authority occurred in managing forest area. The community only acts as a laborer and the plan on facilitation of social forestry by maximize the role of community has not seen yet. While in village's land, the management by farmer group had conducted well under Head of Village supervision. The main problem in this activity was difficulty of access to the demonstration plot location (in spite of accessed by axle vehicle) and it has an impact on the lack of intensive control of the location.

\section{CONCLUSION}

The specific objective of the project on the improvement of community welfare has not been fully assessed due to the short time of evaluation. In this case, the term of project implementation which is only 3 (three) years. in relation with FLR activity achievement, it is still not showing satisfactory results on restoring

Table 2. The amount of existed plants in the three model locations

\begin{tabular}{|c|c|c|c|c|c|c|}
\hline \multirow{3}{*}{ No. } & \multirow{3}{*}{ Location } & \multirow{3}{*}{$\begin{array}{l}\text { Area } \\
\text { (ha) }\end{array}$} & \multicolumn{4}{|c|}{ The amount of seedlings planted (Dec 2016) } \\
\hline & & & \multicolumn{2}{|c|}{ Kayu Bawang } & \multicolumn{2}{|c|}{ Durian } \\
\hline & & & Number (pcs) & $\%$ & Number (pcs) & $\%$ \\
\hline 1 & Giri Mulya Village's land, Seluma & 3 & 1,064 & 99.07 & 146 & 82.95 \\
\hline 2 & $\begin{array}{l}\text { LPF Air Talo - Seluma and Protection } \\
\text { FMU of Seluma }\end{array}$ & 2 & 340 & 69.96 & 12 & 7.79 \\
\hline 3 & $\begin{array}{l}\text { Limas Jaya Village, LPF Air Ketahun } \\
\text { and Production FMU of North } \\
\text { Bengkulu }\end{array}$ & 5 & 1,795 & 97.61 & 220 & 76.92 \\
\hline
\end{tabular}


and improving the forest and land functions. However, the others objective of the project have been fully achieved through delivery of all planned outputs.

The project outputs were accomplished through an adequate process involving the community and main stakeholders to participate and took an initiative on FLR activity by using promoted prospective local plants.

Regarding to the result of model activity as a pilot, the project not only observed the wood potential, but also the potential of non-wood products from Bentara Durian. For example, through the continuous maintenance, it was estimated that Bentara Durian will produce fruits at the age of 6-7 years. Bentara Durian is a high quality variety of durian and combination of Kayu Bawang - Bentara Durian will benefit to the community.

The presence of Bentara Durian in the location model could be developed for other business opportunities. When Bentara Durian stands harvested, the model location and its surrounding can be developed into the adventure and nature tour packages combined with culinary tour of Bentara Durian. This is one of the project efforts to attract the community to be actively involved in the model offered.

\section{REFERENCES}

[1] Usmin, Kerusakan Hutan di Bengkulu Capai 657.049 Hektare. Berita Satu, 2017, http://www.beritasatu.com/nasional/457980kerusakan-hutan-di-bengkulu-capai-657049hektare.html

[2] A.A. Nawir, Murniat, L. Rumboko, Rehabilitasi Hutan di Indonesia. Akan Ke Manakah Arahnya Setelah Lebih Dari Tiga Dasa Warsa? Bogor, Indonesia: Center for International Forestry Research, 2008

[3] International Tropical Timber Organization. (n.d). Improving Forest Functions in Bengkulu Province Through Community Participation in Rehabilitation of Degraded Forest by Using Local Prospective Commodities. Project Document. PD 477/07 Rev. 4 (F).

[4] E.A. Waluyo, A. Nurlia, "Rekayasa Kelembagaan Dalam Pengembangan Hutan Rakyat Kayu Bawang" in Suhartoyo, H. \& Ulya N. A. (Ed.) Bunga Rampai Kayu Bawang: Unggulan Hutan Rakyat Sumatera. Palembang: Tunas Gemilang Press, 2018

[5] H. Gusmara, G. Senoaji., Yansen, R. Saepudin, Kamboya, Teknik Perbanyakan Dan Pemeliharaan Durian Bentara. International Tropical Timber Organization (ITTO) PD 477/07 Rev. 4 (F).
(Second Edition), Direktorat Perbenihan Tanaman Hutan, 2018

[6] Yansen, Analisis Vegetasi dan Indeks Produktivitas Lahan pada Lokasi Demontration Plots. Laporan Teknis, tidak diterbitkan, International Tropical Timber Organization (ITTO) PD 477/07 Rev. 4 (F), 2016 